\title{
Floodplain Preconditioning of Leaf Litter Modulates the Subsidy of Terrestrial $C$ and Nutrients in Fluvial Ecosystems
}

\author{
Rubén del Campo, ${ }^{1,5 *} \odot$ Eugènia Martí, ${ }^{2} \odot$ Elliot Bastias, ${ }^{2,3} \odot$ \\ Gonzalo G. Barberá, ${ }^{4} \odot$ María del Mar Sánchez-Montoya, ${ }^{1} \odot$ and \\ Rosa Gómez ${ }^{1}$
}

\begin{abstract}
${ }^{1}$ Department of Ecology and Hydrology, International Excellence Campus for Higher Education and Research of the University of Murcia, Murcia, Spain; ${ }^{2}$ Integrative Freshwater Ecology Group, Centre for Advanced Studies of Blanes (CEAB-CSIC), Blanes, Spain; ${ }^{3}$ Department of Ecology and Environmental Science, Umea University, Umea, Sweden; ${ }^{4}$ Department of Soil and Water Conservation, CSIC-CEBAS, Murcia, Spain; ${ }^{5}$ Department of Ecology, University of Innsbruck, Technikerstrasse 25, 6020 Innsbruck, Austria
\end{abstract}

\begin{abstract}
Leaf litter can be retained in floodplains for several months before it enters rivers as lateral inputs. During this period, the environmental conditions on the floodplain can alter leaf litter chemistry and, consequently, affect its subsequent processing in the river. We analysed the effect of contrasting floodplain conditions on the chemical composition of leaf litter and its leachates, and how this affected their biodegradability and processing in rivers. To do so, we placed reed leaf litter (Phragmites australis) in open- and closed-canopy habitats of three floodplain sites with contrasting climates (semiarid Mediterranean, humid Mediterranean and continental) for 105 days. We then used litterbags in a
\end{abstract}

Received 2 September 2019; accepted 14 April 2020; published online 14 May 2020

Electronic supplementary material: The online version of this article (https://doi.org/10.1007/s10021-020-00508-5) contains supplementary material, which is available to authorized users.

Authors Contributions: RdC and RG conceived and designed the study with inputs from EM. RdC led the field sampling and laboratory analysis with contributions by RG, EB and MMSM. GGB performed the data analysis with contributions by RdC. RdC and RG led the writing of the manuscript. The rest of the co-authors critically revised the manuscript and gave their final approval for its publication.

*Corresponding author; e-mail: ruben.del-campo@uibk.ac.at river to examine the decomposition of preconditioned leaf litter in comparison with a control (nonpreconditioned litter), and laboratory assays to examine the biodegradation of their leachates. Contrasting conditions on the floodplain prompted differences in the nutrient content of leaf litter among floodplain sites. Preconditioning caused a generalized decline in the $\mathrm{C}$ content and an increase in the lignin content of leaf litter. Even so, preconditioning did not affect litter decomposition rates in the river, although it did reduce decomposition efficiency and biodegradability of leachates. Shredder colonization of litter was variable and generally higher on preconditioned litter, but not significantly so. Different floodplain conditions had no influence on the aquatic processing of preconditioned litter. Our results demonstrate that the retention of leaf litter in terrestrial environments can affect $\mathrm{C}$ budgets of fluvial ecosystems and the recipient food web by reducing the input and the biodegradability of $\mathrm{C}$ and nutrients.

Key words: Terrestrial-aquatic continuum; Floodplains; Decomposition; Organic matter dynamics; Rivers; Carbon biodegradability; Leaf litter. 


\section{HighLights}

- The retention of leaf litter in floodplains reduces its $\mathrm{C}$ biodegradability

- Floodplain conditions did not affect litter decomposition rates in the river

- Lateral leaf inputs may provide less C and nutrients to rivers than vertical inputs

\section{INTRODUCTION}

A large fraction of the terrestrial organic matter production eventually reaches freshwaters (Battin and others 2008). Within this pool, riparian leaf litter and its leachates can be one the most important subsidies of energy in many fluvial ecosystems (for example, headwaters, forested streams) (Wallace and others 1995; Bernhardt and McDowell 2008; Tank and others 2010). Indeed, leaf litter is not only an important resource of carbon (C) and nutrients for the decomposer and detritivore community (Baer and others 2001; Graça 2001), but also its leachates can represent an important supply of dissolved organic carbon (DOC) and nutrients for both heterotrophic and autotrophic bacteria (Meyer and others 1998; Wymore and others 2015).

The processing of leaf litter and its leachates by freshwater consumers depends greatly on their chemical composition (Webster and Benfield 1986; Wymore and others 2015). Thus, the origin of leaf litter and processes affecting it before it enters the river can be, to some extent, pivotal for the functioning of fluvial ecosystems (see Abelho and Descals 2019, Mora-Gómez and others 2019). Leaf litter can reach the river directly by vertical inputs from riparian canopy, but also laterally, washing into the river after having accumulated in floodplains for several months (Bell and Sipp 1975; Jacobson and others 1999). While retained in floodplains, leaf litter can be affected by biotic (for example, microbial and invertebrates activity) and abiotic (for example, photodegradation and rainmediated leaching) processes, which can alter its chemical composition and biodegradability and, consequently, affect its later processing in rivers (Baldwin 1999; Fellman and others 2013; del Campo and Gómez 2016; Abelho and Descals 2019; Mora-Gómez and others 2019). The combination of processes that leaf litter undergoes before it enters the river is known as "preconditioning".

The environmental conditions of floodplains can influence the relative importance and intensity of abiotic and biotic processes during preconditioning. In turn, floodplain environmental conditions are regulated at both regional and local scales (Austin 2011; Wang and others 2014). For instance, in temperate-mesic regions, the high humidity and nutrient content of floodplain soils facilitate the onset of leaf litter decomposition by terrestrial microorganisms (Gavazov and others 2014; Delgado-Baquerizo and others 2015). As a result, microbial activity causes an enrichment of C-recalcitrant compounds in leaf litter due to the immobilization of phenolic compounds (Melillo and others 1984), which in turn can decrease the biodegradability of leaf litter and its leachates (Baldwin 1999; Fellman and others 2013). On the contrary, in open floodplains in warm arid regions, the scarcity of water limits microbial decomposition of leaf litter while the intense solar radiation can promote the loss of lignin by photodegradation (Austin and Ballaré 2010). Consequently, the exposure of litter to solar radiation can result in an increase of its biodegradability (Pu and others 2014; Austin and others 2016). Solar radiation and heat can also negatively influence the biodegradability of leaf litter leachates by increasing the solubility of organic matter, thus favouring the loss of nutrients and $\mathrm{C}$ compounds during rain events (del Campo and others 2019). Beyond regional climatic particularities, environmental conditions within a given floodplain can also change locally among different types of habitats (Langhans and others 2008). For instance, differences in vegetation canopy (that is, open- and closed-canopy areas) can modulate the incidence of solar radiation, the temperature, or the content of organic matter and nutrients in soils (Naiman and others 2005). Therefore, how leaf litter is chemically altered during its retention in floodplains may depend on the interaction between local and regional environmental drivers. However, we still lack studies analysing the influence of floodplain preconditioning on leaf litter chemical composition under contrasting environmental conditions, and how this affects the biodegradability of the particulate and dissolved organic matter fractions of leaf litter in rivers.

Our objective was to analyse how contrasting environmental conditions (at both regional and local scales) during floodplain preconditioning affect the chemical composition of leaf litter and its leachates, and in turn, how this influences their biodegradability and subsequent processing by microbial and invertebrate consumers in rivers. To tackle this objective, we exposed reed leaf litter (Phragmites australis) in open-canopy and closedcanopy habitats of three floodplain sites located in 
three climatic regions (semiarid Mediterranean, humid Mediterranean and continental). Then, we evaluated the effect of preconditioning on the biodegradability of leaf litter and its leachates by conducting a field decomposition experiment in a river and a laboratory experiment, respectively. To disentangle the contribution of microbial activity to terrestrial preconditioning and leaf litter decomposition in the river, we analysed microbial enzymatic activity and fungal biomass besides the mass loss on leaf litter during these two phases. Based on previous studies of organic matter photodegradation and decomposition in terrestrial environments (for example, Moorhead and Sinsabaugh 2006; Brand and others 2010; Austin and others 2016), we hypothesized solar radiation and soil humidity to be the main environmental factors controlling the chemical alteration of leaf litter during the floodplain preconditioning. Thus, we predicted that leaf litter preconditioned under more intense solar radiation (open-canopy $>$ closed-canopy habitats, arid floodplain $>$ mesic floodplains) will contain a lower fraction of lignin due to the higher influence of photodegradation during preconditioning and consequently will be more biodegradable and more decomposed in the river. On the contrary, leaf litter preconditioned under higher humidity (closed-canopy $>$ open-canopy habitats, mesic floodplains $>$ arid floodplain) will be subjected to a greater microbial activity; therefore, it will contain a higher fraction of recalcitrant compounds as lignin and consequently will be less biodegradable and less decomposed in the river.

\section{Materials and Methods}

\section{Field Experiment of Leaf Litter Preconditioning}

To evaluate the effect of preconditioning on leaf litter across different bioclimatic environments, we selected river floodplains from three regions (floodplain sites). Parra (PA; $38^{\circ} 13^{\prime} 54.70^{\prime \prime} \mathrm{N}, 1^{\circ} 5^{\prime}$ $17.00^{\prime \prime} \mathrm{W}$; Murcia, SE Spain) is an open wide floodplain with scarce shrubby vegetation and characterized by a semiarid Mediterranean climate. Tordera (TOR; $41^{\circ} 43^{\prime} 08.3^{\prime \prime} \mathrm{N}, 2^{\circ} 33^{\prime} 50.6^{\prime \prime} \mathrm{E}$; Gerona, NE Spain) is a humid Mediterranean floodplain, mostly dominated by shrub vegetation but also with riparian trees, mostly black poplar (Populus nigra), sparsely distributed over the landscape. Demnitzer (DEM; 52 21 $34.76^{\prime \prime} \mathrm{N}, 14^{\circ} 11^{\prime}$ $44.02^{\prime \prime} \mathrm{E} ;$ Branderburg, NE of Germany) is a floodplain with humid continental climate and a well-developed forest canopy. At each floodplain site, we selected open-canopy habitats (areas of bare soil totally exposed to weathering conditions) and closed-canopy habitats (areas of soil fully shaded by trees or shrubby vegetation).

For this experiment, we collected reed leaf litter in a wetland from the PA region. After air-drying for 2 days, $5 \mathrm{~g}$ of leaf litter were sewed to plastic mesh frames $(20 \times 20 \mathrm{~cm})$. In each floodplain site, we defined a $100-\mathrm{m}$ transect and divided it into three sectors. In each sector, leaf litter packs were split between open- and closed-canopy habitats, fixed to the soil with nails, and incubated for 105 days (August to November 2014). In total, 108 leaf litter packs were deployed in the floodplains. We used 18 packs ( 3 floodplain sites $\times 3$ sectors $\times 2$ habitats) to analyse the effect of floodplain preconditioning on the chemical composition of leaf litter and its leachates, as well as leaf litter mass loss, microbial enzymatic activity and fungal biomass (see details below). The other 90 packs were used to evaluate the effect of floodplain preconditioning on leaf litter decomposition in the river. To characterize environmental conditions of floodplains and habitats, we collected soil samples at the beginning of the preconditioning experiment to analyse texture (FAO 2006), organic matter content (Robertson and others 1999) and elemental composition (C, N, P, K, Ca, Fe, Mg, Na, S) (see details below). Additionally, we collected soil samples monthly in every floodplain site and habitat to measure the gravimetric water content (GWC) (Robertson and others 1999). Finally, we obtained climatic data for each floodplain site from the closest meteorological stations (PA: Charco Taray-Fortuna station, Agrarian Information System of Murcia; TOR: Santa Coloma de Farnés station, Meteorological Service of Catalonia; DEM: Müncheberg station, Climate Data Centre of Deutscher Wetterdienst).

\section{Field Experiment of Leaf Litter Decomposition in the River}

To analyse the influence of the floodplain preconditioning of leaf litter on its aquatic breakdown, we conducted a decomposition experiment in the $\mathrm{Al}-$ hárabe river, located within the upper catchment

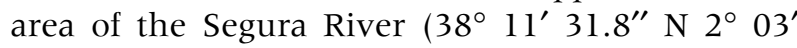
21.1" W; Murcia, Spain), from January to April in 2015. For this assessment, we used a single river in order to conduct the leaf litter incubations under the same aquatic environmental conditions so effects of different preconditioning conditions could be easier to evaluate. Alhárabe is a third-order, non-polluted river characterized by an open ripar- 
ian vegetation canopy, abundant macrophytes (Typha latifolia and Potamogeton coloratus) and a riverbed substrate composed of pebbles and sand.

For the aquatic decomposition experiment, we prepared closed coarse litterbags $(4 \mathrm{~mm}$ mesh size to allow the access of macroinvertebrates) containing leaf litter preconditioned from the two habitats of the three floodplain sites, and also nonpreconditioned leaf litter used as a control. A total of 105 litterbags (90 from the preconditioning experiment plus 15 controls) were randomly distributed at three spots with running flow along a $100-\mathrm{m}$ reach in the river. The litterbags were tied to iron rods fixed in the riverbed. We collected litterbags after 1, 7, 20, 48 and 89 days of incubation. Collected litter bags were kept wet and cold $\left(\sim 4^{\circ} \mathrm{C}\right)$ until later processing in the laboratory. On each sampling date, we collected river water samples in triplicate to analyse the concentration of DOC, ammonium $\left(\mathrm{N}-\mathrm{NH}_{4}{ }^{+}\right)$, nitrate $\left(\mathrm{N}-\mathrm{NO}_{3}{ }^{-}\right)$, and soluble reactive phosphorus (SRP). Water samples were filtered in the field through pre-combusted glass fibre filters (GF/F) (Whatman, Maidstone, UK) and analysed within $24 \mathrm{~h}$ after collection. Additionally, we measured in situ water electrical conductivity, dissolved oxygen, $\mathrm{pH}$ and temperature at the three running flow spots using probes (Intellical HQD, Hach Lange, Loveland, CO, USA). We measured flow velocity at the location of the litterbags with a current meter (MiniAir2; Schiltknecht Co., Zurich, Switzerland) and estimated river discharge at two sites along the river reach based on cross-section measurements of width, water depth, and water velocity.

\section{Laboratory Processing of Leaf Litter Samples}

Leaf litter samples collected from the preconditioning and the aquatic decomposition experiments were processed in the same way in the laboratory. For each sample, we washed all leaves with tap water, then selected five random leaves and cut three sets of five leaf discs with a cork borer (11 $\mathrm{mm}$ in diameter) for further analyses (mass loss, microbial enzymatic activity and fungal biomass, see below). The remaining material of each leaf litter sample and the set of discs designated for mass loss analyses were oven-dried $\left(60{ }^{\circ} \mathrm{C}\right.$, for $24 \mathrm{~h})$ and weighed to obtain their dry mass (DM). Finally, the set of discs for DM was combusted $\left(500{ }^{\circ} \mathrm{C}, 4 \mathrm{~h}\right)$ to calculate the ash-free dry mass (AFDM).

\section{Chemical Composition of Leaf Litter and Floodplain Soils}

$\mathrm{C}$ and $\mathrm{N}$ content of leaf litter and floodplain soils were analysed in oven-dried and ground samples in a LECO Tru-Spec CN analyser (LECO Corp., MI, USA). In addition, $\mathrm{P}, \mathrm{Na}, \mathrm{K}, \mathrm{Ca}, \mathrm{Fe}, \mathrm{Mg}$ and $\mathrm{S}$ contents were analysed by an ICP-OES analyser ICAP 6500Duo (Thermo Fisher Scientific Inc., MA, USA). Analysis of the cellulose and lignin content in leaf litter followed the method described by Goering and Van Soest (1970). The content of the different compounds and elements was expressed as a percentage of total DM of the sample.

\section{Estimates of Leaf Litter Mass Loss and Decomposition Rates}

For the preconditioning experiment, we estimated the mass loss of leaf litter by subtracting the final AFDM of leaf litter packs from their initial AFDM (Bärlocher 2005). For the aquatic decomposition experiment, we used the mass loss of leaf litter over the incubation time in the river to compute the decomposition rate $\left(k\right.$ expressed in day $\left.{ }^{-1}\right)$. $k$ was calculated using the exponential decay model: $M_{t}=M_{0} e^{-k t}$; where $M_{t}$ and $M_{0}$ are the AFDM (g) at incubation times $\mathrm{t}$ and 0 (in days), respectively (Bärlocher 2005).

\section{Microbial Enzymatic Activity}

We used the extracellular enzymatic activity of cellobiohydrolase $(\mathrm{CBH})$ as a proxy of the microbial decomposition activity in leaf litter samples from both preconditioning and aquatic decomposition experiments. $\mathrm{CBH}$ (EC 3.2.1.91) was measured using the fluorogenic model substrate 4-methylumbelliferyl $\beta$-D-cellobioside (MUF-cellobioside) following Hendel and Marxsen (2005) but using an acetic acid buffer $(50 \mathrm{mM}, \mathrm{pH}=5)$ instead of water as the diluent for the sample incubation (German and others 2011). Analyses were always run on fresh leaf disc subsamples within $48 \mathrm{~h}$ after sampling. The $\mathrm{CBH}$ activity was estimated following recommendations by German and others (2011) and expressed as the amount of MUF substrate produced per $\mathrm{g}$ of leaf litter DM and incubation time (in $\mu$ mols MUF-cellobioside $\mathrm{g} \mathrm{DM}^{-1} \mathrm{~h}^{-1}$ ). For the aquatic decomposition experiment, we also computed the $\mathrm{CBH}$ efficiency $\left(k_{\mathrm{CBH}}\right)$ according to Sinsabaugh and others (2002). CBH efficiency represents the enzymatic activity needed to decompose $1 \mathrm{~g}$ of leaf litter and can be used as a proxy for microbial decomposition efficiency, providing information about the energetic cost of 
decomposition for microbial communities. CBH efficiency was computed as the slope of the regression between the natural logarithm of the remaining AFDM of leaf litter and the accumulated enzymatic activity (AEA). AEA of $\mathrm{CBH}$ was estimated by linearly interpolating the mean of $\mathrm{CBH}$ between sampling dates and summing up the obtained values during the river incubation period.

\section{Fungal Biomass}

We measured the fungal biomass (FB) in leaf litter samples from both preconditioning and aquatic decomposition experiments using the ergosterol concentration in the leaf tissues in a set of leaf litter discs frozen at $-80{ }^{\circ} \mathrm{C}$ (Gessner 2005). The frozen leaf litter discs were lyophilised and weighed. Lipids were extracted using $\mathrm{KOH}-$ methanol solution at $80{ }^{\circ} \mathrm{C}$ for $30 \mathrm{~min}$. The extracted lipids were purified using solid-phase extraction cartridges (Waters Sep-Pak ${ }^{\circledR}$, Vac RC, 500 mg, tC 18 cartridges, Waters Corp., Milford, MA, USA). Finally, ergosterol was eluted using isopropanol and quantified by HPLC with absorbance detection at $282 \mathrm{~nm}$ (Agilent 6220; Agilent Technologies, Santa Clara, CA, USA). The ergosterol values are expressed as $\mu \mathrm{g} \mathrm{g} \mathrm{DM}^{-1}$.

\section{Shredder Density}

All macroinvertebrates found in litterbags from the aquatic decomposition experiment were separated and preserved in $70 \%$ ethanol until sorting. Individuals were identified at the family level, separated by feeding strategy and counted. The densities of shredders (DS) were expressed as individuals $\mathrm{g} \mathrm{DM}^{-1}$.

\section{Leaf Litter Leachates Extraction}

We produced aqueous leachates from control and preconditioned leaf litter from all floodplain sites and habitats. Leachates were prepared by placing $0.2 \mathrm{~g}$ of leaf litter in $300 \mathrm{~mL}$ of Milli-Q water in pre-combusted glass beakers, which were shaken at $4{ }^{\circ} \mathrm{C}$ for $24 \mathrm{~h}$ in the dark. After $24 \mathrm{~h}$, leachates were immediately filtered through pre-combusted GF/F filter and stored. Subsamples for the biodegradability assays and the spectroscopic characterization of the leached dissolved organic matter (DOM) were stored at $4{ }^{\circ} \mathrm{C}$ and analysed within 3 days after leachates preparation. Subsamples for concentration of DOC and nutrients were frozen at $-20{ }^{\circ} \mathrm{C}$ until analysis.

\section{Nutrients and DOC Analyses}

We analysed $\mathrm{N}-\mathrm{NO}_{3}{ }^{-}, \mathrm{N}-\mathrm{NH}_{4}{ }^{+}$and SRP in leaf litter leachates and river water samples by standard colorimetric analyses (APHA 2005) in a Systea EasyChem autoanalyser (Frosinone, Italy). The dissolved inorganic nitrogen concentration (DIN) was calculated as the sum of $\mathrm{N}-\mathrm{NO}_{3}{ }^{-}$and $\mathrm{N}-\mathrm{NH}_{4}{ }^{+}$. DOC was analysed in pre-acidified samples with a Shimadzu TOC-5000A analyser (MD, USA).

\section{Spectroscopic Characterization of DOM of Leaf Litter Leachates}

Absorbance was measured within a wavelength range from 250 to $500 \mathrm{~nm}$ (in $0.2-\mathrm{nm}$ increments) using a Shimadzu UV1700 spectrophotometer (Shimadzu Corporation, Kyoto, Japan). From the absorbance data, we computed the spectral slope for 275-295 nm (S275-295), the ratio between the slopes in wavelength regions $275-295$ to $350-400$ (Sr) (Helms and others 2008), the ratio of decadal absorptions at 250 and $365 \mathrm{~nm}$ (E2:E3) (De Haan and De Boer 1987), and the SUVA 254 index as the decadal absorption coefficient at $254 \mathrm{~nm}$, divided by the DOC concentration (values expressed as L $\mathrm{mg} \mathrm{C}^{-1} \mathrm{~m}^{-1}$ ). S275-295, Sr and E2:E3 are usually employed as surrogates for DOM molecular size (De Haan and De Boer 1987; Helms and others 2008), while SUVA254 is used as a proxy of DOM aromaticity (Weishaar and others 2003). Fluorescence was measured within an emission wavelength range from 300 to $500 \mathrm{~nm}$ (in $0.2-\mathrm{nm}$ increments) at two discrete excitation wavelengths (254 and $370 \mathrm{~nm}$ ) in a Hitachi F450 fluorescence spectrophotometer to compute the humification index (HIX) and the fluorescence index (FI). HIX can be used as an indicator of the humic-like DOM, whereas FI is often used as an indicator of DOM origin and the presence of DOM labile compounds. HIX was calculated as the peak area of the emission wavelengths from 435 to $480 \mathrm{~nm}$, divided by the peak area of the emission wavelengths from 300 to $445 \mathrm{~nm}$ at an excitation wavelength of $254 \mathrm{~nm}$ (Zsolnay and others 1999). FI was calculated as the ratio of emission intensity at $450 \mathrm{~nm}$ to that at $500 \mathrm{~nm}$ for an excitation wavelength of $370 \mathrm{~nm}$ (McKnight and others 2001).

\section{Leaf Litter Leachates Biodegradability Assay}

We used the Resazurin-Resorufin $\left(\mathrm{R}_{\mathrm{az}}-\mathrm{R}_{\mathrm{ru}}\right)$ chemical system as a proxy to measure biodegradability of leaf litter leachates. This method is based on the transformation of $R_{a z}$ into $R_{r u}$, which is used as a 
tracer of respiration in aquatic ecosystems (see Haggerty and others 2008; González-Pinzón and others 2012). Thus, we assumed the higher the $R_{r u}$ production rates in leachates, the higher the respiration, and thus their biodegradability. To measure $\mathrm{R}_{\mathrm{ru}}$ production in leachates we incubated $0.2 \mu \mathrm{m}$-filtered leachates (cellulose acetate membrane filters; ABLUO ${ }^{\circledR}$ GVS, Sanford. USA) with a microbial inoculum (aqueous extract of the Alhárabe river sediments filtered by pre-combusted $\mathrm{GF} / \mathrm{F}$ filter) and a $\mathrm{R}_{\mathrm{az}}$ solution (final concentration of $200 \mu \mathrm{g} \mathrm{R}_{\mathrm{az}} \mathrm{L}^{-1}$ ) for $\mathrm{l} \mathrm{h}$ at room temperature and darkness. We measured the increase in $\mathrm{R}_{\mathrm{ru}}$ over time by measuring fluorescence at $571 \mathrm{~nm}$ excitation and the $602 \mathrm{~nm}$ emission. $\mathrm{R}_{\mathrm{ru}}$ production rates were expressed as mmol $R_{\mathrm{ru}} \mathrm{g} \mathrm{DM}^{-1} \mathrm{~h}^{-1}$.

\section{Data Analysis}

As a first exploratory step, we used principal component analyses (PCA) to explore differences in leaf litter and leachates between the control and the preconditioned leaf litter and among floodplain sites and habitats. All the variables were $\mathrm{z}$-standardised prior to the PCAs.

We used linear mixed-effects models to evaluate the influence of floodplain environmental conditions at both regional and habitat scale on the chemical composition of leaf litter and leachates, the biodegradability of leachates for river microbiota and the leaf litter decomposition (that is, decomposition rate, $\mathrm{CBH}$ activity and efficiency, fungal biomass and shredder density). To do so, we built models with floodplain site ( 3 levels: PA, TOR, DEM) and habitat (2 levels: open- and closed-canopy) as fixed factors. The same model design was used for the preconditioning and the aquatic decomposition experiments. The only differences between models were (1) the inclusion of the floodplain sector as a random factor nested to the floodplain site in the preconditioning model, and (2) the inclusion of the incubation time in the river (5 sampling dates) as a covariable in the aquatic model. We tested the post hoc differences between the levels of the fixed factors by Tukey's test.

We also analysed the global effect of floodplain preconditioning on leaf litter and leachate chemical composition and processing by a priori contrast analyses, where we compared the performance of preconditioned leaf litter with the control. For this comparison, we expected floodplain sites to have greater influence than habitat characteristics; thus, we split the category "preconditioned leaf litter" into the three floodplain sites. This way, we formulated the null hypothesis of the a priori contrast test as: $\mu_{\mathrm{CT}}=1 / 3 \mu_{\mathrm{PA}}+1 / 3 \mu_{\mathrm{TOR}}+1 / 3 \mu_{\mathrm{DEM}}$. In other words, the mean of the control leaf litter $\left(\mu_{\mathrm{CT}}\right)$ is equal to the mean obtained from the leaf litter preconditioned in three floodplain sites $\left(\mu_{\mathrm{PA}}+\mu_{\mathrm{TOR}}+\mu_{\mathrm{DEM}}\right)$. Post hoc differences among floodplain levels were tested with Tukey's test.

We used Spearman correlations to explore possible drivers (environmental conditions of floodplains or chemical composition of leaf litter or leachates) of terrestrial and aquatic leaf litter decomposition and leachate biodegradability. Additionally, we included the leaf litter processing parameters (mass loss, fungal biomass, $\mathrm{CBH}$ activity or shredder density) as supplementary variables in the PCAs mentioned previously to show graphically the possible relationships between leaf litter decomposition and its environmental or chemical drivers.

The mixed models and contrast analyses were implemented with PROC MIXED of SAS 9.4. PCAs were built with $\mathrm{R}$ version 3.2.1 ( $\mathrm{R}$ Core Team 2015).

\section{RESUlts}

\section{Environmental Conditions of Floodplain Sites and Habitats}

The first two components of the PCA explained up to $75.5 \%$ of the variance in floodplain soil properties and climatic conditions among study sites (Figure 1B). The two components clearly separated the three floodplain sites. Differences between PA and DEM were mostly associated with PCl, whereas differences with TOR were also associated with PC2 (Figure 1B). The floodplain of PA was characterized by the highest air temperature and the lowest air relative humidity, gravimetric water content, soil organic matter, $\mathrm{N}$ and $\mathrm{P}$ contents. The floodplain of DEM showed opposite characteristics of PA. The features of the floodplain of TOR were intermediate between PA and DEM. Even so, TOR was distinguished by the greatest accumulation of precipitation and the highest content of $\mathrm{P}$ and $\mathrm{Fe}$ in soils. The PCA did not clearly differentiate between floodplain habitats. According to the mixed models, only DEM showed differences in the soil content of $\mathrm{N}$ and $\mathrm{P}$ between habitats, which were higher in the closed-canopy than in the open-canopy habitat $\left(\mathrm{N}: \quad F_{2,11}=6.71, \quad p<0.05 ; \quad \mathrm{P}: \quad F_{2,11}=6.53\right.$, $p<0.05$ ) (Table S1). 

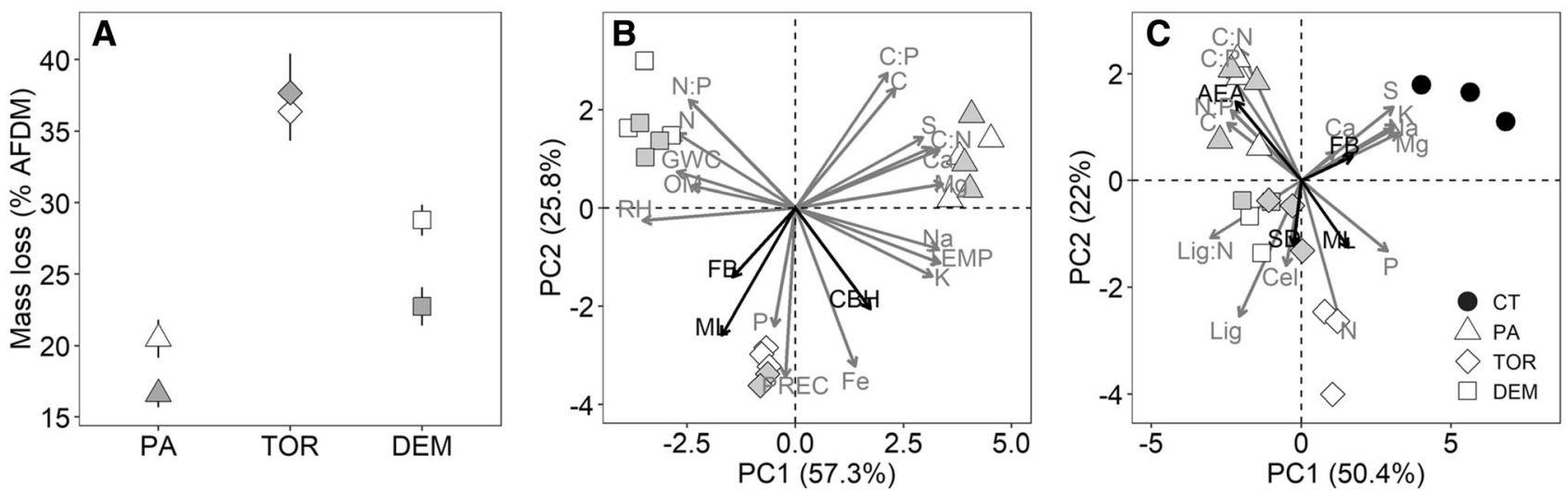

Figure 1. A Leaf litter mass loss in floodplain sites and habitats during the preconditioning experiment. B, C Biplots describing PCA results from: B the environmental conditions and soil properties of all floodplain sites and habitats during the preconditioning experiment; and $\mathbf{C}$ the chemical composition of the control and the preconditioned leaf litter at the end of the preconditioning experiment. Different symbols indicate results for the leaf litter preconditioned in the different floodplain sites (PA, TOR, DEM) and the control (CT). Black dots correspond to the control, while white and grey symbols correspond to open- and closed-canopy habitats, respectively. Grey arrows represent the loading of each environmental or chemical variable used to perform each PCA. Black arrows show decomposition variables included as supplementary variables in the PCA analysis. They represent the correlation of mass loss (ML), cellobiohydrolase activity (CBH), accumulated enzymatic activity (AEA), fungal biomass (FB) and shredder density (SD) with the PCA components. Floodplain sites: $\mathrm{PA}=$ Parra, $\mathrm{TOR}=$ Tordera, $\mathrm{DEM}=$ Demnitzer.

\section{Effects of the Floodplains' Environmental Conditions on Leaf Litter Chemical Composition and its Terrestrial Processing}

The first two components of the PCA based on leaf litter chemical composition ( $\mathrm{N}, \mathrm{P}, \mathrm{Ca}, \mathrm{K}, \mathrm{Mg}, \mathrm{Na}, \mathrm{S}$, cellulose and lignin) accounted for $72.4 \%$ of the total variance of control and preconditioned leaf litter (Figure 1C). The PCA results showed clear chemical differences between control and preconditioned leaf litter (as also demonstrated by the contrast analyses, see Table 1). Preconditioned leaf litter showed higher lignin content and lower nutrient content (mainly $\mathrm{Ca}, \mathrm{K}, \mathrm{Mg}$, $\mathrm{Na}$ and $\mathrm{S}$, but also $\mathrm{N}$ and $\mathrm{P}$ ) than control leaves (Figure 1C). The PC2 separated the leaf litter exposed in PA from that exposed in TOR and DEM due to its lower $\mathrm{N}$ and $\mathrm{P}$ content.

According to mixed model results, the greatest differences in leaf litter chemical composition were found among floodplain sites, especially in the $\mathrm{P}$ content and the elemental ratios (C:N, C:P and N:P) (P: $F_{2,6}=24.96, p<0.001 ; \quad \mathrm{C}: \mathrm{N}: F_{2,6}=10.26$, $p<0.05 ; \quad \mathrm{C}: \mathrm{P}: \quad F_{2,6}=85.04, \quad p<0.001 ; \quad \mathrm{N}: \mathrm{P}:$ $\left.F_{2,6}=43.73, p<0.001\right)$. In particular, leaf litter in PA resulted clearly differentiated from leaf litter exposed in the other two sites (Tukey, $p<0.05$ ). Differences between floodplain habitats were again very scarce, with only some differences associated with the $\mathrm{N}$ content of leaf litter (Table 1).
Leaf litter mass loss after its exposure in floodplains ranged between 19 and $37 \%$ of the initial AFDM (Figure 1A). The largest differences in leaf litter mass loss, $\mathrm{CBH}$ activity and fungal biomass during the preconditioning were found among floodplain sites (mass loss: $F_{2,85}=60.67$, $p<0.001$; $\mathrm{CBH}: F_{2,45}=8.59, p<0.05$; fungal biomass: $\left.F_{2,15}=6.06, p<0.05\right)$. In general, leaf litter in TOR showed the highest values of mass loss, CBH and fungal biomass, while leaf litter in PA presented the lowest ones. Differences between floodplain habitats were only significant for the mass loss $\left(F_{1,86}=4.33, p<0.05\right)$, with a higher mass loss in the open-canopy habitats. In floodplains, all leaf litter decomposition variables showed strong negative correlations with soil elemental ratios (Figure 1B). Mass loss and fungal biomass were negatively correlated to $\mathrm{C}: \mathrm{N}$ (mass loss: $r=-0.69, p<0.05$; fungal biomass: $r=-0.53, p<0.05$ ) and $\mathrm{C}: \mathrm{P}$ ratios (mass loss: $r=-0.83, p<0.001$; fungal biomass: $r=-0.53$, $p<0.05)$, whereas CBH was negatively correlated to $\mathrm{N}: \mathrm{P}(r=-0.68, p<0.05)$. Significant correlations were also found between climatic conditions and decomposition variables. Mass loss was positively correlated to the accumulated precipitation $(r=0.77, p<0.001)$, the air relative humidity $(r=0.53, p<0.05)$, and $\mathrm{CBH}$ activity to air temperature $(r=0.67, p<0.05)$. 


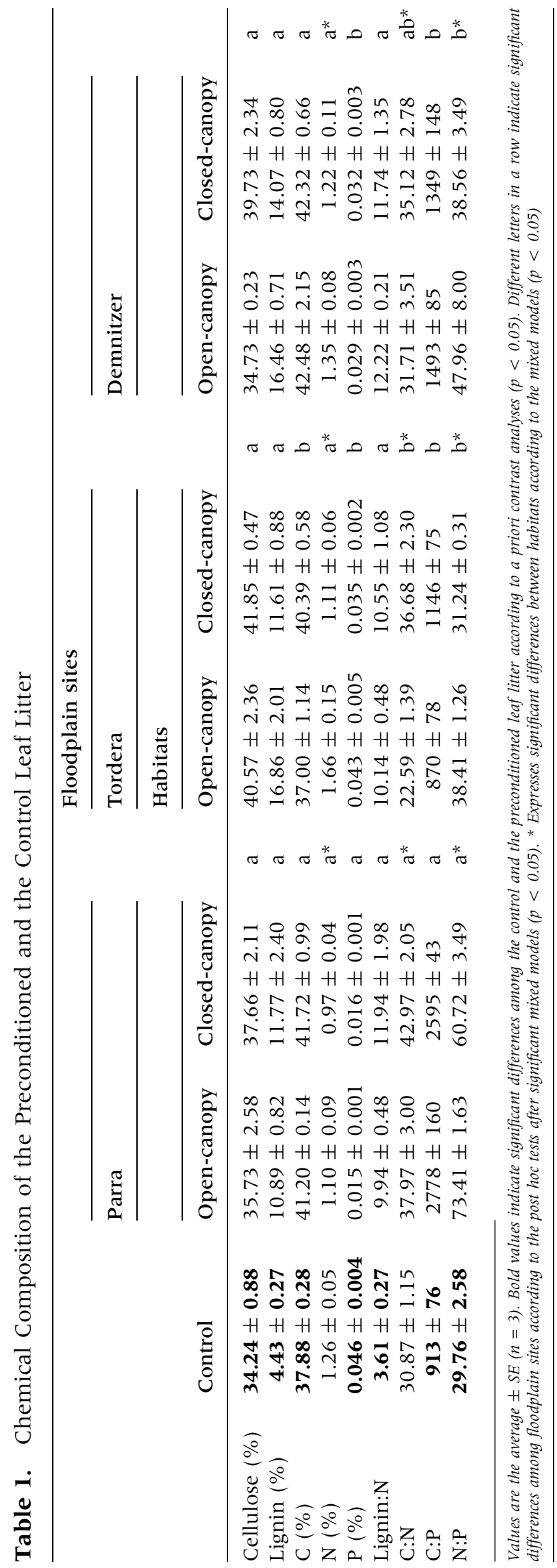




\section{River Environmental Conditions}

During the aquatic decomposition phase, the average river discharge was $113 \mathrm{~L} \mathrm{~s}^{-1}$ and water electrical conductivity was $800 \mu \mathrm{S} \mathrm{cm} \mathrm{cm}^{-1}$. Water temperature ranged from 2.9 to $12.1^{\circ} \mathrm{C}$. River water was well-oxygenated (ca. $95 \%$ oxygen saturation) and had a basic $\mathrm{pH}$ of around 8 . The DIN concentration was relatively low $(421 \pm 107 \mu \mathrm{g}$. $\mathrm{L}^{-1}$ ) and was dominated by $\mathrm{N}-\mathrm{NO}_{3}{ }^{-}$. The average SRP concentration was less than $1 \mu \mathrm{g} \cdot \mathrm{L}^{-1}$.

\section{Effects of Floodplains' Environmental Conditions on the Aquatic Decomposition of Leaf Litter}

The aquatic decomposition rate of preconditioned leaf litter showed no differences with respect to the control $\left(\mathrm{t}_{1,15}=1.35 ; p>0.05\right)$, neither among floodplain sites $\left(F_{2,10}=0.89 ; p>0.05\right)$ nor between habitats $\left(F_{1,10}=1.12 ; p>0.05\right)$ (Table 2), although the decomposition rate of leaf litter in TOR was slightly higher than in the other two floodplain sites (Figure 2A). In contrast, the decomposition efficiency (proxy of the energetic cost of decomposition for microbial communities) was significantly lower in the preconditioned than in the control leaf litter $\left(\mathrm{t}_{1,10}=2.99 ; p<0.05\right)$ (Figure 2B, Table 2). We also found differences in decomposition efficiency among leaf litter that was preconditioned in different floodplains, particularly leaf litter decomposition efficiency from PA was lower than that from TOR $\left(F_{2,9}=9.84 ; p<0.05\right.$. Tukey: $p<0.05)$.

Differences in bulk CBH activity and fungal biomass between preconditioned and control leaf litter varied over the incubation time in the river. Preconditioned leaf litter exhibited higher accrual of $\mathrm{CBH}$ and fungal biomass values than the control only during the first 20 days of river incubation (Figure 3A, B). Afterwards, differences disappeared due to the exponential increase of $\mathrm{CBH}$ and fungal biomass in the control. Floodplain site was the main factor driving differences in $\mathrm{CBH}$ and fungal biomass in decomposing leaf litter. Leaf litter from PA presented the highest $\mathrm{CBH}$ values $\left(F_{2,155}=66.57 ; p<0.001\right.$. Tukey: $\left.p<0.001\right)$, whereas leaf litter from TOR showed the highest fungal biomass values $\left(F_{2,51}=8.56 ; p<0.001\right.$. Tukey $p<0.05)$. Differences between floodplain habitats were only significant for $\mathrm{CBH}$, which showed higher values in the leaf litter preconditioned at open-canopy habitats $\left(F_{1,155}=16.17\right.$; $p<0.001)$. Shredder density was variable and generally higher in preconditioned leaf litter at the end of the immersion period; however, no significant differences were found among preconditioned and control leaf litter, neither among floodplain sites or habitats $\left(\mathrm{t}_{1,76}=0.13, \quad p>0.05\right.$; $F_{2,51}=1.29 ; p>0.05$ and $F_{1,51}=0.20 ; p>0.05$, respectively (Figure $3 \mathrm{C}$ ).

Most of the studied aquatic decomposition variables showed significant correlations with the initial content of P in the leaf litter (Figure 1C). Mass loss and fungal biomass were positively correlated (mass loss: $r=0.55, p<0.05$; fungal biomass: $r=0.56, p<0.05)$, whereas AEA was negatively correlated $(r=-0.64, p<0.05)$. Other significant correlations were found between the fungal biomass and the leaf litter content of $\mathrm{K}(r=0.72$, $p<0.001)$ or $\mathrm{S}(r=0.50, p<0.05)$, or between AEA and all elemental ratios (C:N: $r=0.55$, $p<0.05$; C:P: $r=0.87, p<0.001 ; \mathrm{N}: \mathrm{P}: r=0.82$, $p<0.001)$.

\section{Effects of Floodplains' Environmental Conditions on the Chemical Composition and Biodegradability of Leaf Litter Leachates}

The PCA based on the chemical composition of leachates explained up to $70.85 \%$ of the total variance of control and preconditioned leaf litter (Figure 4A). Results from PCA showed clear

Table 2. Decomposition Rate and Decomposition Efficiency of the Preconditioned and the Control Leaf Litter

\begin{tabular}{|c|c|c|c|c|c|c|}
\hline & & & & Floodplain site & & \\
\hline & Control & Preconditioned & Parra & Tordera & & Demnitzer \\
\hline $\mathrm{k}\left(\mathrm{d}^{-1}\right)$ & $0.0050 \pm 0.0005$ & $0.0043 \pm 0.0002$ & $0.0041 \pm 0.0004 \quad \mathrm{a}$ & $0.0047 \pm 0.0003$ & a & $0.0042 \pm 0.0004 \quad a$ \\
\hline $\mathrm{k}_{\mathrm{CBH}}\left(\mu \mathrm{mol}^{-1}\right)$ & $0.0106 \pm 0.0005$ & $0.0070 \pm 0.0006$ & $0.0048 \pm 0.0010 \quad a$ & $0.0095 \pm 0.0010$ & $\mathrm{~b}$ & $0.0072 \pm 0.0010 \quad a b$ \\
\hline
\end{tabular}



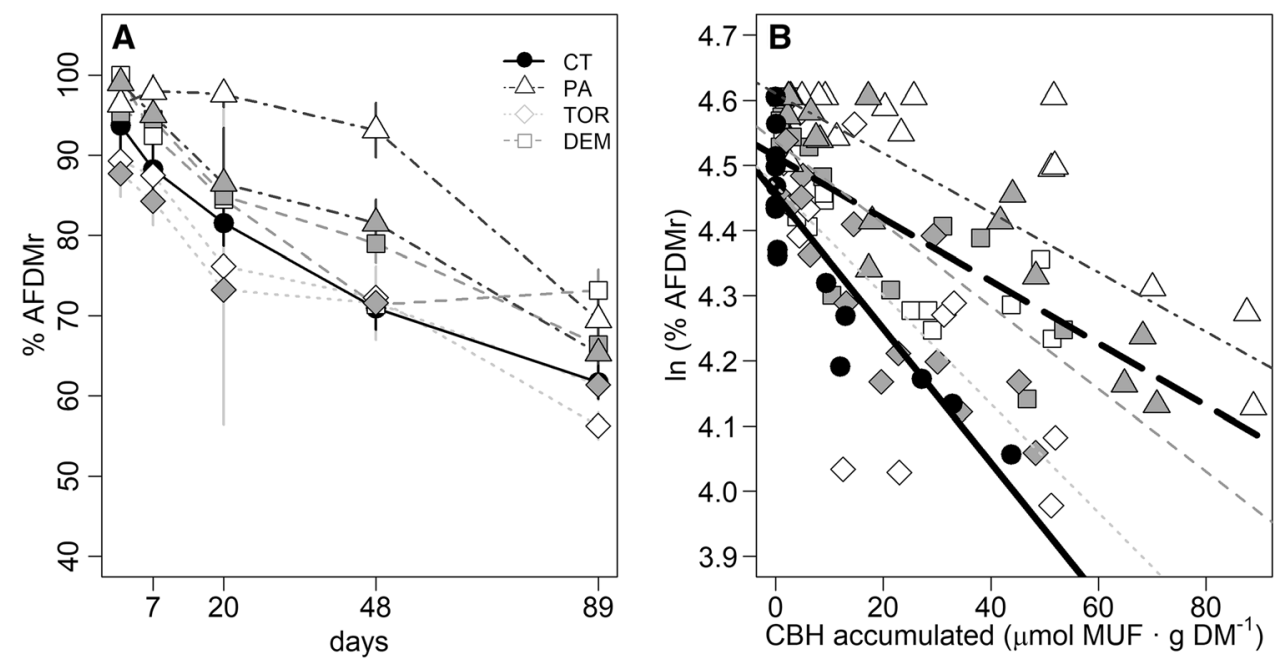

Figure 2. A Leaf litter mass loss over the incubation period in the river. B Relationship between the natural log of remaining leaf litter biomass (\% AFDMr) and the cellobiohydrolase activity (CBH) accumulated during each sampling date. In $\mathrm{B})$, The slope of the regressions represents the decomposition efficiency $\left(\mathrm{k}_{\mathrm{CBH}}\right.$ in $\mu$ mol of cellobiohydrolase produced to decompose a gram of leaf litter). The black line represents the results for control leaf litter (CT), while the black dashed line represents the average results for all the leaf litter preconditioned in the study floodplains. Different grey lines and symbols represent data from different floodplain sites (PA, TOR, DEM). Black dots correspond to the control, while white and grey symbols correspond to open- and closed-canopy habitats, respectively. Points are average values \pm SE $(n=3)$. Floodplain sites: $\mathrm{PA}=$ Parra, $\mathrm{TOR}=$ Tordera, $\mathrm{DEM}=$ Demnitzer

chemical differences between control and preconditioned leaf litter (also evidenced by the contrast analyses, see Table S2). Preconditioned leaf litter showed much lower concentration of DOC and nutrients (DIN, SRP) than the control. Also, labile DOM compounds were lower in preconditioned litter as indicated by lower FI values. PC1 reflected differences in the composition of leaf litter leachates among floodplain sites. This axis separated PA leachates from DEM and TOR leachates due to the lowest nutrient concentration in PA (as indicated by the highest C:N, N:P and C:P values), but also because their highest values in s275-296 and HIX (Figure 4A, Table S2), which suggest the dominance of large, humic DOM compounds. On the other hand, the leachates from leaf litter preconditioned in TOR and DEM were characterised by high Sr and E2:E3 values, indicating the dominance of small DOM compounds.

The mixed models confirmed the greatest differences among floodplain sites were found principally between PA and the couple DEM-TOR (Table S2). We only found significant differences between habitats for HIX $\left(F_{1,11}=1.96 ; p<0.05\right)$, with the higher values (that is, higher DOM humification) in the open-than in the closed-canopy habitat.

The $R_{\text {ru }}$ production rate was significantly lower in leachates of preconditioned leaf litter than in the control $\left(\mathrm{t}_{1,15}=22.9 ; p<0.001\right)$, indicating a clear decrease of the biodegradability of leachates (Figure $4 \mathrm{~B}) . \mathrm{R}_{\mathrm{ru}}$ production rate significantly differed among floodplain sites $\left(F_{2,10}=7.35 ; p<0.05\right)$, with leaf litter leachates from PA presenting the highest values. No differences between habitats were found $\left(F_{1,10}=0.20 ; p>0.05\right)$. The $\mathrm{R}_{\mathrm{ru}}$ production rate was highly correlated to FI $(r=0.53$, $p<0.05)$, DOC $(r=0.90, p<0.001)$ and DIN concentrations $(r=0.85, p<0.001)$, but it was negatively correlated to $\mathrm{Sr}$ and E2:E3 $(r=-0.6$, $p<0.05$ both) (Figure 4A). Furthermore, $\mathrm{R}_{\mathrm{ru}}$ production rate showed a great negative relationship with the lignin content of leaf litter $\left(\mathrm{r}^{2}=0.6\right.$, $p<0.001$ ) (Figure 4C) .

\section{Discussion}

Contrary to our predictions, despite the wide range of environmental conditions in our study floodplain sites, floodplain conditions had only a minor influence on the chemical composition of leaf litter and leachates, mainly by altering the nutrient content. These minor alterations, however, did not promote any differences in the biodegradability of leaf litter preconditioned in the different floodplain sites or in its processing in the river. 


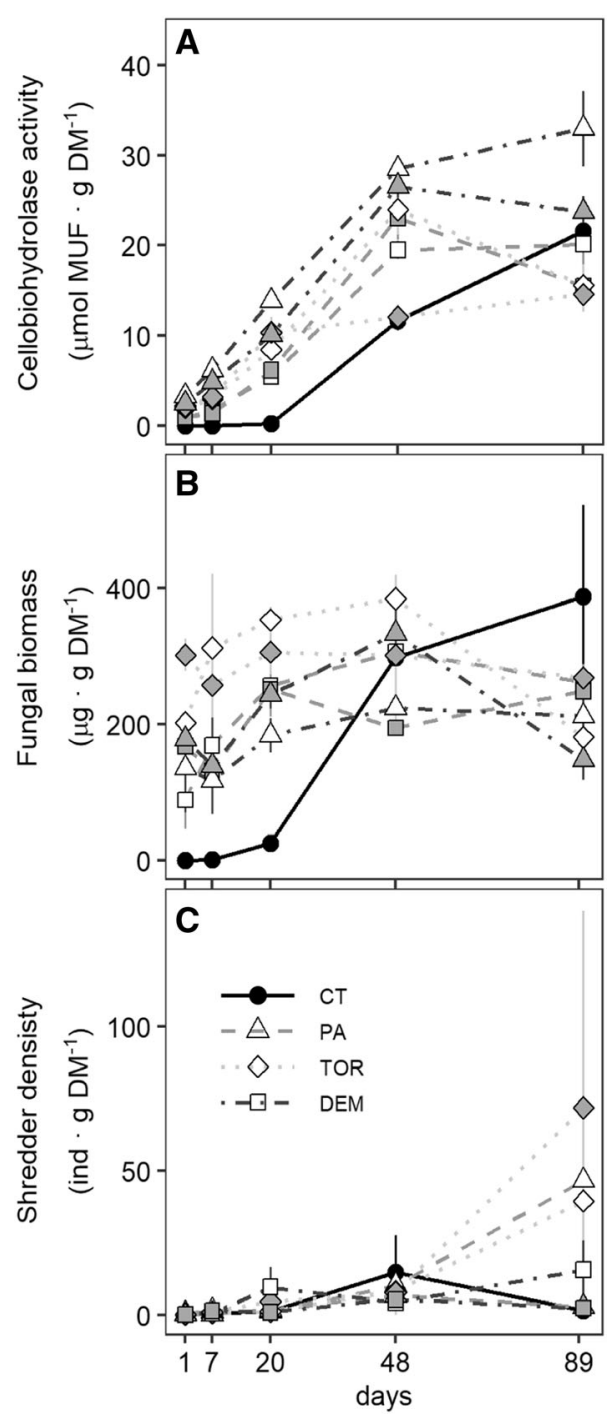

Figure 3. Temporal variation of $\mathbf{A}$ cellobiohydrolase activity, B fungal biomass and $\mathbf{C}$ shredder density during the leaf litter incubation in the river. Different lines and symbols indicate results for the leaf litter preconditioned in the different floodplain sites (PA, TOR, DEM) and the control (CT). Black dots correspond to the control, while the white and grey symbols correspond to open- and closed-canopy habitats, respectively. Points are average values \pm SE $(n=3)$. Floodplain sites: $\mathrm{PA}=$ Parra, $\mathrm{TOR}=$ Tordera, $\mathrm{DEM}=$ Demnitzer.

\section{Floodplain Preconditioning Increases Leaf Litter C Recalcitrance but has a Variable Effect on Leaf Nutrients Depending on Floodplain Soil Environmental Conditions}

The environmental conditions of terrestrial ecosystems can regulate which abiotic or biotic processes affect leaf litter decomposition (Austin 2011) and therefore explain differential changes in leaf litter chemical composition (del Campo and others 2019). Based on previous works on organic matter decomposition in arid lands, we expected leaf litter exposed to intense solar radiation, such as in open-canopy habitats or in the more arid floodplains, to undergo a decrease of lignin due to photodegradation (see Austin and Ballaré 2010; $\mathrm{Pu}$ and others 2014; del Campo and Gómez 2016). On the contrary, we observed a large general increase of lignin in leaf litter exposed in all floodplain habitats and sites (up to three times the initial composition, see Table 1). These results are in line with some other studies (Baldwin 1999; Fellman and others 2013; Zheng and others 2018, MoraGómez and others 2019) that show how the partial decomposition of leaf litter in riparian habitats can result in the microbial immobilization of complex phenolic compounds and the concurrent increase of lignin and other recalcitrant compounds. Consequently, our results suggest that preconditioning, independently of the floodplain environmental conditions, causes a general ageing of leaf litter C, increasing its recalcitrance and consequently reducing its biodegradability.

In contrast, the nutrient content of leaf litter was differently affected by the different environmental conditions of floodplain soils (Aerts 1997; DelgadoBaquerizo and others 2015) (Figure 1 and Table 1). Leaf litter exposed in TOR maintained a high nutrient content, especially of $\mathrm{P}$, similar to control leaf litter. However, the leaf litter exposed in DEM underwent a great loss of $\mathrm{P}$ (up to the $47 \%$ of the initial content), while PA leaf litter experimented a drastic loss of both $\mathrm{N}$ and P (up to 37 and $74 \%$ of the initial content, respectively). We suggest such contrasting results among floodplains were driven by differences in the net balance between microbial nutrient immobilisation and nutrient loss by rain leaching during the preconditioning period (Parton and others 2007). We hypothesized that only the combined presence of nutrient-rich soils and high humidity in TOR resulted in favourable conditions to allow $\mathrm{P}$ immobilization in leaf litter $\left(\mathrm{O}^{\prime}\right.$ Connell 1994; Liu and others 2006). In contrast, the loss of nutrients during rain events would dominate in PA and TOR, especially so in PA, since high temperatures and solar radiation have been shown to increase nutrients solubility in leaf litter (Bärlocher 1992; del Campo and others 2019). We recognize that further analyses should be done to confirm this hypothesis about the relationship between the soil nutrient content and the capacity of terrestrial decomposers to immobilize $\mathrm{P}$, as our analyses did not distinguish between the bioavailable and nonbioavailable $\mathrm{P}$ fraction in soils. Besides the alter- 

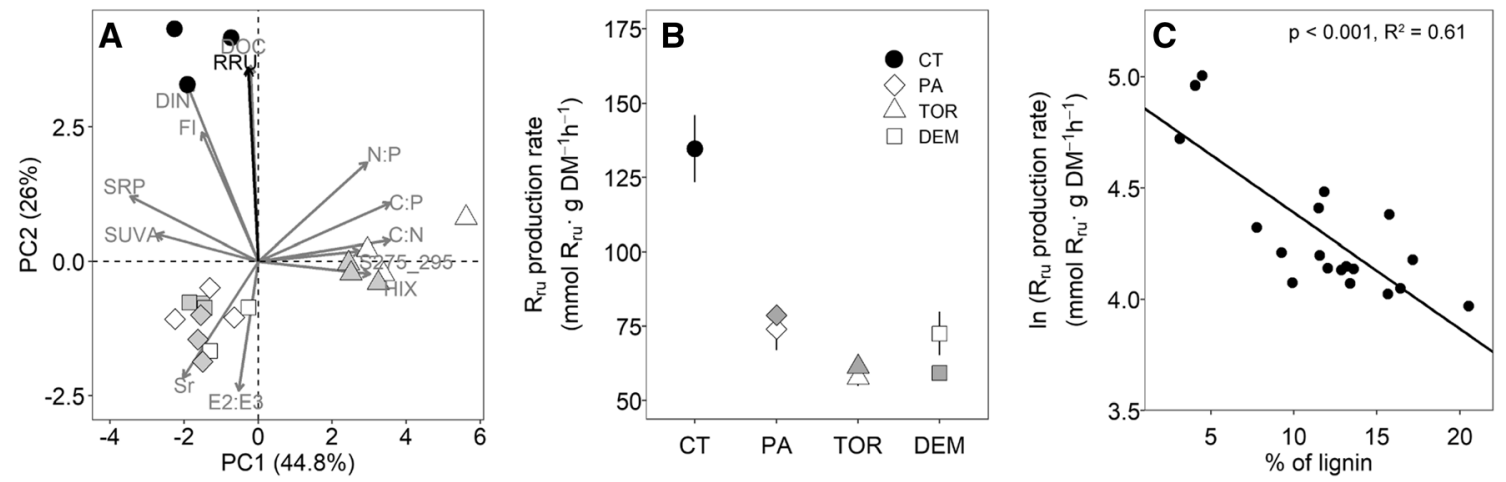

Figure 4. A PCA biplot describing the chemical composition of leaf litter leachates. $\mathbf{B} \mathrm{R}_{\mathrm{ru}}$ production rate (mean \pm SE; $n=3$ ) measured during the leachates biodegradability assay. C Relationship between the logarithm of the $\mathrm{R}_{\mathrm{ru}}$ production rate and the lignin content of preconditioned and control leaf litter. The higher the lignin content of leaf litter, the lower the $\mathrm{R}_{\mathrm{ru}}$ production rate, and thus the biodegradability of leachates. Different symbols in $\mathbf{A}$ and $\mathbf{B}$ show the results for the leaf litter preconditioned in the different floodplain sites (PA, TOR, DEM) and the control (CT). Black dots correspond to the control, while the white and grey symbols correspond to open- and closed-canopy habitats, respectively. In A, the grey arrows represent the loading of the different chemical descriptors used to perform the PCA, while the black arrow shows the projection of the $\mathrm{R}_{\mathrm{ru}}$ production rate included in the PCA as a supplementary variable. Floodplain sites: PA = Parra, TOR $=$ Tordera, DEM $=$ Demnitzer.

ation of the $\mathrm{N}$ and $\mathrm{P}$ content, the retention of leaf litter in the floodplains caused a general depletion in other nutrients like $\mathrm{K}, \mathrm{Mg}$, $\mathrm{Na}$ or S (del Campo and Gómez 2016).

\section{Floodplain Preconditioning Does Not Alter the Decomposition Rate of Leaf Litter in the River But Reduces its Decomposition Efficiency}

Contrary to our expectations, neither contrasting floodplain conditions nor the general decrease of $\mathrm{C}$ quality in leaf litter during preconditioning affected decomposition rates in the river (Figure 2, Table 2). Similarly, other studies showed no influence of terrestrial preconditioning on leaf litter decomposition rates in rivers (Dieter and others 2011, 2013; Abelho and Descals 2019; Mora-Gómez and others 2019; but see Pu and others 2014). We hypothesize this lack of an effect could be due to a counterbalance between distinct chemical and physical features of the leaf litter acquired during preconditioning. On one hand, preconditioning increases leaf litter recalcitrance (due to the increase of lignin, but also the decrease of labile $\mathrm{C}$ compounds as found for leachates, see below), which can slow down its microbial decomposition (Zheng and others 2018; Mora-Gómez and others 2019). On the other hand, the more advanced state of decomposition in preconditioned leaves can result in an increase of mass loss by fragmentation, either by the action of flowing water or by leaf-shredding invertebrates, as might be suggested by the higher (although not significant) shredder density in preconditioned leaf litter (Figure 3C). To disentangle the effect of preconditioning on the processing of leaf litter by shredders, future studies should perform feeding laboratory experiments.

On the other hand, similar to previous studies, we found preconditioning can shape the pathway by which leaf litter is processed by microbial communities in the river. In similar works, Abelho and Descals (2019) and Mora-Gómez and others (2019) show how the combination of the increase of leaf litter recalcitrance, together with its colonization by terrestrial fungal communities during its floodplain exposure, can alter both the composition of the aquatic decomposer communities and the way it is processed in the river. Furthermore, Mora-Gómez and others (2019) found preconditioning alters the enzymatic route used by microorganisms to decompose leaf litter in the river. Similar to our results, they found an increase of cellobiohydrolase activity in preconditioned leaf litter compared to the control, most likely as a consequence of their unequal availability of $\mathrm{C}$ resources (Moorhead and Sinsabaugh 2006; del Campo and Gómez 2016). The higher enzyme production but similar mass loss of preconditioned leaf litter compared to the control indicates a decrease of the decomposition efficiency in the preconditioned litter. In other words, microbial decomposers in preconditioned leaves needed to invest more energy in enzyme production to decompose the same amount of organic matter as those in the control. This result might suggest floodplain preconditioning can re- 


\section{Vertical leaf litter inputs}

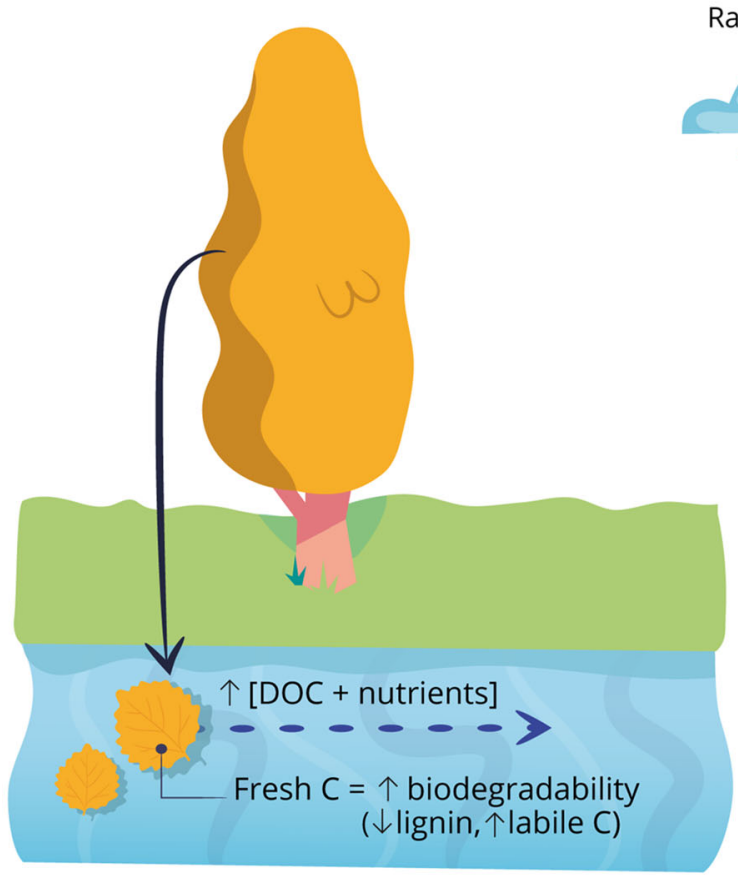

Lateral leaf litter inputs

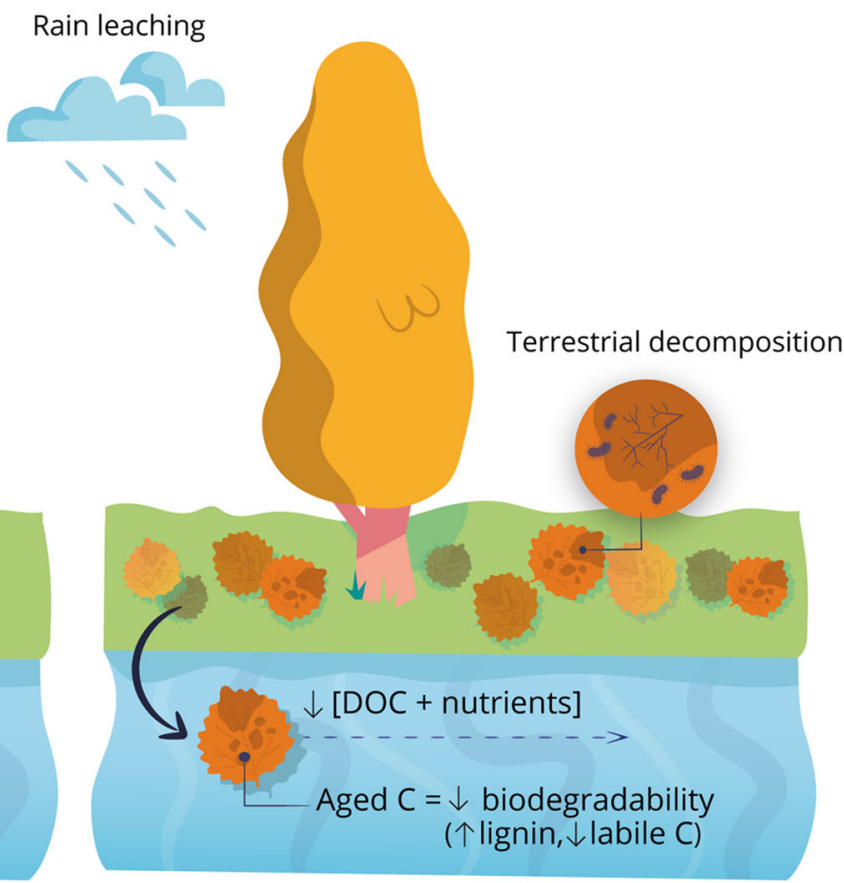

Figure 5. Conceptual diagram showing differences in the aquatic processing of leaf litter entering the river via vertical and lateral inputs. Dashed arrows indicate DOC and nutrient fluxes provided by leaf litter leachates. Solid lines indicate the quality of the $\mathrm{C}$ compounds provided by leaf litter and leachates to the aquatic consumers. Briefly, the combination of terrestrial microbial decomposition and rain leaching of leaf litter during its retention in floodplain soils causes: (1) a reduction of the load of $\mathrm{C}$ and nutrients entering the river as leaf litter leachates, and (2) a decrease of $\mathrm{C}$ biodegradability due to the increase of its recalcitrance. Graphic art by Patricia Tudela Rosique.

duce the net energy subsidy from riparian leaf litter to aquatic food webs. Even so, we recognize the limitations of our conclusion since it is supported by the result of only one enzyme. Therefore, this conclusion should be tested in future field experiments by using a more complete set of enzymes.

\section{Floodplain Preconditioning Reduces the Relevance of Leaf Litter Leachates as a Source of $\mathrm{C}$ and Nutrients for Freshwater Communities}

Floodplain preconditioning resulted in a marked drop in the concentration of DOC, nutrients and labile DOM compounds (suggested by the decrease in FI) in leaf litter leachates from all floodplain sites and habitats (Figure 4A, Table S2), most probably as a result of the combined action of terrestrial microbial decomposition and rain leaching (Hongve and others 2000; O'Connell and others 2000). Such depletion led to a sharp decline in leachate biodegradability as indicated by the decrease of the $\mathrm{R}_{\mathrm{ru}}$ production rate in comparison with the control, and the positive correlations of $\mathrm{R}_{\mathrm{ru}}$ production rate with DOC, DIN and the FI index (Figure 4A). $R_{r u}$ production rate correlated inversely with DOM molecular size indexes ( $\mathrm{Sr}$ and E2:E3), which suggests that the small DOM compounds found in the leachates from the TOR and DEM leaf litters had poor biodegradability (Amon and Benner 1996). Furthermore, we also found $\mathrm{R}_{\mathrm{ru}}$ production rate was strongly negatively related to the lignin content of leaf litter (Figure 4C). This result is in line with other studies which observed that the accumulation of recalcitrant compounds in litter fibres during preconditioning can reduce the biodegradability of their leachates (Baldwin 1999; Fellman and others 2013; del Campo and others 2019). In conclusion, our results indicate that the preconditioning of leaf litter in floodplains could severely reduce the relevance of leachates as a source of energy and nutrients for aquatic food webs, although we acknowledge that longer $(>1 \mathrm{~h})$ biodegradation assays should be carried out to confirm our findings. 


\section{Implications of Terrestrial-Aquatic Interactions on $\mathrm{C}$ Processing in Rivers}

Leaf litter is an important resource of $\mathrm{C}$ and nutrients for freshwater ecosystems either in the form of particulate or dissolved organic matter (Bernhardt and McDowell 2008; Hagen and others 2012). Our findings indicate that the combined action of microbial decomposition and rain leaching experienced by leaf litter during its retention in terrestrial riparian ecosystems can result in a considerable loss of its $\mathrm{C}$ and nutrients, reducing then the lateral input of those resources to aquatic food webs (Figure 5). According to our data, the retention of leaf litter in floodplain soils for 3 months can cause the loss up to: $37 \%$ of particulate organic matter, $16 \%$ of particulate $\mathrm{C}, 37 \%$ of particulate $\mathrm{N}$, $74 \%$ of particulate $\mathrm{P}$, but also the loss up to $29 \%$ of DOC, $82 \%$ of DIN and $85 \%$ of SRP from leaf litter leachates. Furthermore, in the line of recent previous studies (Zheng and others 2018; Abelho and Descals 2019; Mora-Gómez and others 2019), the floodplain preconditioning can increase the recalcitrance of particulate $\mathrm{C}$ and decreased the biodegradability of DOC (Baldwin 1999; Fellman and others 2013; Mora-Gómez and others 2019). The combination of both chemical changes in leaf litter can hinder the heterotrophic microbial activity in streams, demanding a higher energy investment to microbial consumers to degrade these terrestrial $\mathrm{C}$ resources. However, due to the lack of consistent effects of preconditioning on leaf litter decomposition rates in rivers in this and other studies, we should be careful about the implications of preconditioning on the microbial decomposition of particulate leaf litter.

Our results highlight the necessity of continuing to investigate the effect of floodplain preconditioning on the processing of organic matter in rivers to gain a realistic understanding of the $C$ fluxes between terrestrial and aquatic ecosystems. However, we recognize that the global effect of exposure of leaf litter in floodplains on river ecosystem functioning would depend on the proportion of leaf litter that enters rivers from floodplains in relation to leaf litter entering directly to rivers (lateral vs. vertical inputs). Furthermore, results from this work should be also considered for the study of $\mathrm{C}$ cycling in intermittent rivers (see del Campo and others 2019; Mora-Gómez and others 2019), where coarse organic matter can be exposed in dry riverbeds for long time periods. The expected increase of flow intermittency due to global change could lead to a higher accumulation of leaf and woody litter on dry riverbeds for longer periods of pre- conditioning (Datry and others 2018), and potentially affecting their aquatic decomposition after flow resumption.

\section{ACKNOWLEDGEMENTS}

Open access funding provided by University of Innsbruck and Medical University of Innsbruck. We thank Matthew Talluto for editing the manuscript and anonymous reviewers for providing helpful comments on earlier versions of this manuscript. This research was funded by Project 19525/PI/14 from the Seneca Foundation, Agency for Science and Technology, in Región de Murcia. R. del Campo was funded by a PhD contract (FPU R-269/2014) from the University of Murcia. E. Bastias was funded by a PhD contract (FPI) from the Spanish Ministry of Science and Innovation through the MEDFORESTREAM project (CGL2011-30590-C02-02). M.M. Sánchez-Montoya was financially supported by a Marie-Curie postdoctoral fellowship (330466; MC-IEF; FP7people-2012-IEF). The authors declare no conflict of interest.

\section{OPEN ACCESS}

This article is licensed under a Creative Commons Attribution 4.0 International License, which permits use, sharing, adaptation, distribution and reproduction in any medium or format, as long as you give appropriate credit to the original author(s) and the source, provide a link to the Creative Commons licence, and indicate if changes were made. The images or other third party material in this article are included in the article's Creative Commons licence, unless indicated otherwise in a credit line to the material. If material is not included in the article's Creative Commons licence and your intended use is not permitted by statutory regulation or exceeds the permitted use, you will need to obtain permission directly from the copyright holder. To view a copy of this licence, visit $h$ ttp://creativecommons.org/licenses/by/4.0/.

\section{DATA AVAILABILITY}

Data are available at https://doi.org/10.6084/m9.fig share.12143727.v1.

\section{REFERENCES}

Abelho M, Descals E. 2019. Litter movement pathways across terrestrial-aquatic ecosystem boundaries affect litter colonization and decomposition in streams. Funct Ecol 333:178597. 
Aerts R. 1997. Climate, leaf litter chemistry and leaf litter decomposition in terrestrial ecosystems: a triangular relationship. Oikos 79:439-49.

Amon RMW, Benner R. 1996. Bacterial utilization of different size classes of dissolved organic matter. Limnol Oceanogr 41:41-51.

APHA. 2005. Standard methods for the examination of water and wastewater. Washington DC.

Austin AT. 2011. Has water limited our imagination for aridland biogeochemistry? Trends Ecol Evolut 26:229-35.

Austin AT, Ballaré CL. 2010. Dual role of lignin in plant litter decomposition in terrestrial ecosystems. PNAS 107:4618-22.

Austin AT, Méndez MS, Ballaré CL. 2016. Photodegradation alleviates the lignin bottleneck for carbon turnover in terrestrial ecosystems. PNAS 113:4392-7.

Baer SG, Siler ER, Eggert SL, Wallace JB. 2001. Colonization and production of macroinvertebrates on artificial substrata: upstream-downstream responses to a leaf litter exclusion manipulation. Freshw Biol 46:347-65.

Baldwin DS. 1999. Dissolved organic matter and phosphorus leached from fresh and 'terrestrially' aged river red gum leaves: implications for assessing river-floodplain interactions. Freshw Biol 41:675-85.

Battin TJ, Kaplan LA, Findlay S, Hopkinson CS, Marti E, Packman AI, Newbold JD, Sabater F. 2008. Biophysical controls on organic carbon fluxes in fluvial networks. Nat Geosci 1:95100.

Bell DT, Sipp SK. 1975. The litter stratum in the streamside forest ecosystem. Oikos 26:391-7.

Benfield EF. 1997. Comparison of litterfall input to streams. J N Am Benthol Soc 16:104-8.

Bernhardt ES, McDowell WH. 2008. Twenty years apart: comparisons of DOM uptake during leaf leachate releases to Hubbard Brook Valley streams in 1979 versus 2000. J Geophys Res Biogeosci 113:G03032.

Brandt LA, King JY, Hobbie SE, Milchunas DG, Sinsabaugh RL. 2010. The role of photodegradation in surface litter decomposition across a grassland ecosystem precipitation gradient. Ecosystems 13:765-81

Bärlocher F. 1992. Effects of drying and freezing autumn leaves on leaching and colonization by aquatic hyphomycetes. Freshw Biol 28:1-7.

Bärlocher F. 2005. Leaf mass loss estimated by litter bag technique. In: Graça MAS, Bärlocher F, Gessner MO, Eds. Methods to study litter decomposition. Dordrecht: Springer. p 3742.

Datry T, Foulquier A, Corti R, von D, Schiller, Tockner K, Mendoza-Lera C, J., Clement C, Gessner MO, Moleon M, Stubbington R, Gucker B, Albarino R, D., Allen C, Altermatt F, Arce MI, Arnon S, Banas D, Banegas-Medina A, E., Beller, Blanchette ML, Blanco-Libreros JF, Blessing JJ, Boechat IG, Boersma KS, Bogan MT, Bonada N, Bond NR, Barria KCB, A., Bruder, Burrows RM, Cancellario T, Canhoto C, Carlson SM, S., Cauvy-Fraunie, Cid N, Danger M, Freitas TBd, Girolamo AMD, E B, La d, Campo Rd, Diaz-Villanueva VD, Dyer F, Elosegi A, Faye E, C., Febria, Four B, Gafny S, Ghate SD, Gomez R, Gomez-Gener L, S. MA, Graca, Guareschi S, Hoppeler F, Hwan J, Jones JI, Kubheka S, Laini A, Langhans SD, Leigh C, Little CJ, Lorenz S, Marshall JC, Martin E, A., McIntosh R, Meyer EI, Miliša M, Mlambo MC, Morais M, Moya N, M. P, Negus, Niyogi DK, Papatheodoulou A, Pardo I, Pařil P, Pauls SU, V., Pešić, Polašek M, Robinson CT, Ro-
driguez-Lozano P, Rolls RJ, M. M, Sanchez-Montoya, Savić A, Shumilova O, Sridhar KR, Steward AL, R., Storey, Taleb A, Uzan A, Vorste RV, Waltham NJ, Woelfle-Erskine C, Zak D, Zarfl C, Zoppini A. 2018. A global analysis of terrestrial plant litter dynamics in non-perennial waterways. Nat Geosci 11 : 497-503.

De Haan H, De Boer T. 1987. Applicability of light absorbance and fluorescence as measures of concentration and molecular size of dissolved organic carbon in humic Lake Tjeukemeer. Water Res 21:731-4.

del Campo R, Gómez R. 2016. Exposure of wood in floodplains affects its chemical quality and its subsequent breakdown in streams. Sci Total Environ 543:652-61.

del Campo R, Gómez R, Singer G. 2019. Dry phase conditions prime wet-phase dissolved organic matter dynamics in intermittent rivers. Limnol Oceanogr 64:1966-79.

Delgado-Baquerizo M, García-Palacios P, Milla R, Gallardo A, Maestre FT. 2015. Soil characteristics determine soil carbon and nitrogen availability during leaf litter decomposition regardless of litter quality. Soil Biol Biochem 81:134-42.

Dieter D, Frindte K, Krüger A, Wurzbacher C. 2013. Preconditioning of leaves by solar radiation and anoxia affects microbial colonisation and rate of leaf mass loss in an intermittent stream. Freshw Biol 58:1918-31.

Dieter D, Dv Schiller, García-Roger EM, Sánchez-Montoya MM, Gómez R, Mora-Gómez J, Sangiorgio F, Gelbrecht J, Tockner K. 2011. Preconditioning effects of intermittent stream flow on leaf litter decomposition. Aquat Sci 73:599-609.

FAO. 2006. Guidelines for soil description. Rome.

Fellman JB, Petrone KC, Grierson PF. 2013. Leaf litter age, chemical quality, and photodegradation control the fate of leachate dissolved organic matter in a dryland river. J Arid Environ 89:30-7.

Gavazov K, Mills R, Spiegelberger T, Lenglet J, Buttler A. 2014. Biotic and abiotic constraints on the decomposition of Fagus sylvatica leaf litter along an altitudinal gradient in contrasting land-use types. Ecosystems 17:1326-37.

German DP, Weintraub MN, Grandy AS, Lauber CL, Rinkes ZL, Allison SD. 2011. Optimization of hydrolytic and oxidative enzyme methods for ecosystem studies. Soil Biol Biochem 43:1387-97.

Gessner MO. 2005. Ergosterol as a measure of fungal biomass. In: Graça M, Bärlocher F, Gessner MO, Eds. Methods to study litter decomposition. A practical guide. Dordrecht: Springer.

Goering H, Van Soest P. 1970. Forage fiber analyses (apparatus, reagents, procedures, and some applications). Agricultural handbook no. 379. Washington, DC: Agriculture Research Service, United States Department of Agriculture, p 387-598.

González-Pinzón R, Haggerty R, Myrold D. 2012. Measuring aerobic respiration in stream ecosystems using the resazurinresorufin system. J Geophys Res: Biogeosci 117:G00N06.

Graça MAS. 2001. The role of invertebrates on leaf litter decomposition in streams-a review. Int Rev Hydrobiol 86:383-93.

Hagen EM, McCluney KE, Wyant KA, Soykan CU, Keller AC, Luttermoser KC, Holmes EJ, Moore JC, Sabo JL. 2012. A meta-analysis of the effects of detritus on primary producers and consumers in marine, freshwater, and terrestrial ecosystems. Oikos 121:1507-15.

Haggerty R, Argerich A, Martí E. 2008. Development of a "smart" tracer for the assessment of microbiological activity 
and sediment-water interaction in natural waters: The resazurin-resorufin system. Water Resour Res 44:W00D01.

Helms JR, Stubbins A, Ritchie JD, Minor EC, Kieber DJ, Mopper K. 2008. Absorption spectral slopes and slope ratios as indicators of molecular weight, source, and photobleaching of chromophoric dissolved organic matter. Limnol Oceanogr 53:955-69.

Hendel B, Marxsen J. 2005. Fluorometric determination of the activity of $\beta$-glucosidase and other extracellular hydrolytic enzymes. In: Graça MAS, Bärlocher F, Gessner MO, Eds. Methods to study litter decomposition: a practical guide. Dordrecht: Springer. p 261-6.

Hongve D, Van Hees PAW, Lundström US. 2000. Dissolved components in precipitation water percolated through forest litter. Eur J Soil Sci 51:667-77.

Jacobson PJ, Jacobson KM, Angermeier PL, Don SC. 1999. Transport, retention and ecological significance of woody debris within a large ephemeral river. J N Am Benthol Soc 18:429-44.

Langhans SD, Tiegs SD, Gessner MO, Tockner K. 2008. Leafdecomposition heterogeneity across a riverine floodplain mosaic. Aquat Sci 70:337-46.

Liu P, Huang J, Han X, Sun OJ, Zhou Z. 2006. Differential responses of litter decomposition to increased soil nutrients and water between two contrasting grassland plant species of Inner Mongolia, China. Appl Soil Ecol 34:266-75.

McKnight DM, Boyer EW, Westerhoff PK, Doran PT, Kulbe T, Andersen DT. 2001. Spectrofluorometric characterization of dissolved organic matter for indication of precursor organic material and aromaticity. Limnol Oceanogr 46:38-48.

Melillo JM, Naiman RJ, Aber JD, Linkins AE. 1984. Factors controlling mass loss and nitrogen dynamics of plant litter decaying in Northern streams. Bull Mar Sci 35:341-56.

Meyer JL, Wallace JB, Eggert SL. 1998. Leaf litter as a source of dissolved organic carbon in streams. Ecosystems 1:240-9.

Moorhead DL, Sinsabaugh RL. 2006. A theoretical model of litter decay and microbial interaction. Ecol Monogr 76:151-74.

Mora-Gómez J, Boix D, Duarte S, Cássio F, Pascoal C, Elosegi A, Romaní AM. 2019. Legacy of summer drought on autumnal leaf litter processing in a temporary Mediterranean stream. Ecosystems.

Naiman RJ, Bechtold JS, Drake DC, Latterell JJ, O'Keefe TC, Balian EV. 2005. Origins, patterns, and importance of heterogeneity in riparian systems. In: Lovett GM, Turner MG, Jones CG, Weathers KC, Eds. Ecosystem function in heterogeneous landscapes. New York: Springer. p 279-309.

O'Connell AM. 1994. Decomposition and nutrient content of litter in a fertilized eucalypt forest. Biol Fert Soils 17:159-66.
O'Connell M, Baldwin DS, Robertson AI, Rees G. 2000. Release and bioavailability of dissolved organic matter from floodplain litter: influence of origin and oxygen levels. Freshw Biol 45:333-42.

Parton W, Silver WL, Burke IC, Grassens L, Harmon ME, Currie WS, King JY, Adair EC, Brandt LA, Hart SC, Fasth B. 2007. Global-scale similarities in nitrogen release patterns during long-term decomposition. Science 315:361-4.

Pu G, Du J, Ma X, Lv Y, Jia Y, Jia X, Tian X. 2014. Contribution of ambient atmospheric exposure to Typha angustifolia litter decomposition in aquatic environment. Ecol Eng 67:144-9.

R Core Team. 2015. R: A language and environment for statistical computing.

Robertson GP, Coleman DC, Bledsoe CS, Sollins P. 1999. Standard soil methods for long-term ecological research.

Sinsabaugh RL, Carreiro MM, Repert DA. 2002. Allocation of extracellular enzymatic activity in relation to litter composition, $\mathrm{N}$ deposition, and mass loss. Biogeochemistry 60:1-24.

Tank JL, Rosi-Marshall EJ, Griffiths NA, Entrekin SA, Stephen ML. 2010. A review of allochthonous organic matter dynamics and metabolism in streams. J N Am Benthol Soc 29:118-46.

Wallace JB, Whiles MR, Eggert S, Cuffney TF, Lugthart GJ, Chung K. 1995. Long-term dynamics of coarse particulate organic matter in three Appalachian mountain streams. J N Am Benthol Soc 14:217-32.

Wang J, You Y, Tang Z, Liu S, Sun OJ. 2014. Variations in leaf litter decomposition across contrasting forest stands and controlling factors at local scale. J Plant Ecol 8:261-72.

Webster JR, Benfield EF. 1986. Vascular plant breakdown in freshwater ecosystems. Annu Rev Ecol Syst 17:567-94.

Weishaar JL, Aiken GR, Bergamaschi BA, Fram MS, Fujii R, Mopper K. 2003. Evaluation of specific ultraviolet absorbance as an indicator of the chemical composition and reactivity of dissolved organic carbon. Environ Sci Technol 37:4702-8.

Wymore AS, Compson ZG, McDowell WH, Potter JD, Hungate BA, Whitham TG, Marks JC. 2015. Leaf-litter leachate is distinct in optical properties and bioavailability to stream heterotrophs. Freshw Sci 34:857-66.

Zheng J, Wang Y, Chen C, Jiang Q, Han S, Xu Z. 2018. Effects of inundation and stranding on leaf litter decomposition and chemical transformation. Aquat Sci 80:9.

Zsolnay A, Baigar E, Jimenez M, Steinweg B, Saccomandi F. 1999. Differentiating with fluorescence spectroscopy the sources of dissolved organic matter in soils subjected to drying. Chemosphere 38:45-50. 